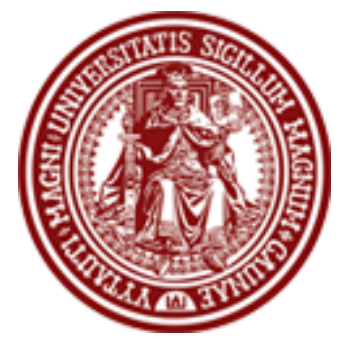

BALTIC JOURNAL OF LAW \& POLITICS

VOLUME 5, NUMBER 1 (2012)

ISSN 2029-0454

http://www.versita.com/bjlp

Cit.: Baltic Journal of Law \& Politics 5:1 (2012): 137-164

DOI: $10.2478 / \mathrm{v} 10076-012-0007-x$

\title{
POLICYHOLDER OBLIGATIONS AFTER AN INSURED EVENT: ARE BALTIC INSURANCE LAWS TOO INSURER-FRIENDLY COMPARED TO THE PRINCIPLES OF EUROPEAN INSURANCE CONTRACT LAW?
}

\author{
Olavi-Jüri Luik \\ Ph.D. student \\ Faculty of Law, University of Tartu (Estonia) \\ Attorney at law in Law Firm LEXTAL (Estonia) \\ Contact information \\ Address: Law Firm LEXTAL, Rävala pst. 4, Tallinn, 10143, Estonia \\ Phone: +3726400250 \\ E-mail address: olavi@lextal.ee
}

Received: July 19, 2012; reviews: 2; accepted: August 10, 2012.

\begin{abstract}
This article explores the differences between the Estonian Law of Obligations Act, the Latvian Insurance Contract Law and Lithuanian rules contained in the Civil Code and Insurance Law in comparison with the Principles of European Insurance Contract Law with regards to the policyholder's obligations after insured event. The three key obligations after insured event, i.e., (i) the obligation to reduce damage, (ii) the obligation to report an insured event, and (iii) the obligation to cooperate, play a major role in the performance obligation of the insurer. It is precisely the proper performance of those obligations that determines how quickly the policyholder receives insurance indemnity, should there be an insured event. Breach of those obligations may in certain cases result in a refusal to pay insurance indemnity. Compared with national laws of the Baltic States, the relevant regulation provided in the PEICL is more favourable and consumer-friendly for policyholders.
\end{abstract}




\section{KEYWORDS}

Insurance contract, Principles of European Insurance Contract Law, loss mitigation, notice of insured event, claims cooperation 


\section{INTRODUCTION}

Currently, there are 27 different contract laws simultaneously in force in the EU, including different regulations of insurance contract law. Hence, the laws regulating insurance contracts differ vastly in Estonia, Latvia and Lithuania. For the consumers, this complicates the purchase of relevant services in another country, both for people who relocate in order to settle and those who work in another country. It also makes cross-border activities complicated and costly, which is why cross-border services are not provided to consumers as a rule. The diversity of contract laws is said by the Commission to discourage cross-border trade and hinder the development by SMEs of a pan-European commercial policy. ${ }^{1}$ The European Commission is currently developing the Common Frame of Reference for European Contract Law which also addresses insurance contracts (Principles of European Insurance Contract Law (hereinafter: PEICL ${ }^{2}$ )). On 8 June 2011, the European Parliament delivered its Resolution on policy options for progress towards a European Contract Law for consumers and businesses, ${ }^{3}$ which advocates the adoption of an Optional Instrument including Insurance Contract Law based on the PEICL. Optional instruments constitute an alternative to national regimes of contract law, hence the reference to a 2 nd regime. ${ }^{4}$ With the 2 nd regime, two regulations are applied in parallel: one is the national insurance contract law and the other is the PEICL as enforced by the European Union. ${ }^{5}$ The parties choose the regulation they want to apply to their contract when entering into an insurance contract.

This article explores the differences between the Estonian Law of Obligations Act $^{6}$ (LOA), Latvian Insurance Contract Law ${ }^{7}$ (ICL), Lithuanian rules contained in

\footnotetext{
${ }^{1}$ Gary Low, "Will firms consider a European optional instrument in contract law?" European Journal of Law and Economics Vol. 33, No. 3 (2012): 521.

2 Draft Common Frame of Reference, Chapter III, Section IX: Insurance Contract, Project Group "Restatement of European Insurance Contract Law" (August 2009) //

http://www.uibk.ac.at/zivilrecht/restatement/sprachfassungen/peicl-en.pdf (accessed July 3, 2012).

3 European Parliament Resolution of 8 June 2011 on Policy Options for Progress towards a European Contract Law for Consumers and Businesses, 2011/2013(INI) //

http://www.europarl.europa.eu/sides/getDoc.do?type=TA\&language=EN\&reference=P7-TA-2011-0262 (accessed July 3, 2012).

4 Helmut Heiss, Malcolm Clarke, and Mandeep Lakhnan, "Europe: Toward a harmonised European insurance contract law-the PEICL": 608; in: Julian Burling and Kevin Lazarus, Research Handbook on International Insurance Law and Regulation (Edward Elgar Publishing Ltd., 2011).

${ }^{5}$ Walter Doract gives the following example of an optional instrument as a choice of the consumer: "On the one hand, it is said that European consumers should have an additional option for the choice of law. This proposal of the optional choice of contract law has been illustrated by the term "blue button" ("blue" as in European). A buyer could click on a blue button when contracting online in cross-border (or, also in purely national) contracts. After a click on the button "Proceed to Checkout" on Amazon.fr or fnac.fr the next page would ask whether the sale should proceed according to the Code Civil or according to the optional European instrument - the blue button" (Walter Doract, "The Optional European Contract Law and why success or failure may depend on scope rather than substance," Max Planck Private Law Research Paper No. 11/9: 8 (June 25, 2011) //

http://papers.ssrn.com/sol3/papers.cfm?abstract_id=1876451 ((accessed August 10, 2012)).

${ }^{6}$ Law of Obligations Act (Estonia), State Gazette (Riigi Teataja), part 1, July 18, 2011, no. 21.
} 
the Civil Code $^{8}$ (CC) and Insurance Law $^{9}$ (IL) and the PEICL as regards the policyholder's duties after insured event. This article purports to analyse whether the PEICL is more consumer-friendly in terms of obligations under an insurance contract, compared to the insurance contract laws of the Baltic States. Estonia, Latvia and Lithuania have been chosen as research objects eo ipso as they represent small neighbouring countries often treated as a single market by large corporations. However, the insurance contract regulations of these three countries are very different and thus the insurance companies that operate in all of them need to develop completely different insurance products. Enforcement of the PEICL would enable such insurance companies that are active in several countries to create harmonised insurance products. However, this, in turn, gives rise to the question of whether or not the PEICL as the so-called 2 nd regime regulation might be more favourable to the consumer than the domestic regulation.

Legal literature often tends to neglect to address the obligations after insured event. However, these three key obligations, i.e., (i) the obligation to reduce damage, (ii) the obligation to report an insured event, and (iii) the obligation to cooperate, play a major role in the performance obligation of an insurer. It is precisely the proper performance of those obligations that determines how quickly the policyholder receives insurance indemnity, should there be an insured event. Breach of those obligations may in certain cases result in refusal to pay insurance indemnity. Giesela Ruhl points out that:

After occurrence of the insured event, all European legal orders as well as Article 6:101 and 6:102 PEICL require the policyholder to disclose and communicate certain information. These duties are usually imposed on the policyholder by law and independently of the insurance contract. This might seem surprising at first blush. After all, the policyholder has an incentive to tell the insurer that an insured event has occurred. However, the duty to disclose and communicate information is also in the interest of the insurer. He has to be able to investigate the factual details surrounding a claim, and he must be able to do so in a timely fashion after the insured event occurred. Since it is normally easier and more economical for the policyholder-due to simple proximity-to determine whether damage has been incurred, he has to inform the insurer about the occurrence of the insured event and the details of the damage sustained. The design of the duty of disclosure and communication is oriented in all legal orders towards the other duties of disclosure that are imposed on the policyholder. ${ }^{10}$

\footnotetext{
7 The Insurance Contract Law (Latvia), Latvian Herald (Latvijas Vēstnesis), no. 188/189, June 30, 1998; no. 15.

${ }^{8}$ The Civil Code of the Republic of Lithuania, Official Gazette (Valstybès žinios), 2000, no. 74-2262.

${ }^{9}$ Law on Insurance (Lithuania), Official Gazette (Valstybès žinios), 2003, no. 94-4246

${ }^{10}$ Giesela Rühl, "Information Obligations (Insurance Contracts)": 5; in: Jürgen Basedow, Klaus Hopt, and Reinhard Zimmermann, eds., Encyclopaedia of European Private Law (Oxford University Press, 2012) // http://papers.ssrn.com/sol3/papers.cfm?abstract_id=1989536 (accessed July 3, 2012).
} 


\section{OBLIGATION TO REDUCE DAMAGE IN THE CASE OF AN INSURED} EVENT

In non-life insurance, the insured person is required to prevent and limit damage in the case of a direct danger or insured event. ${ }^{11}$ Signing an insurance contract does not automatically guarantee that the policyholder is released from the common due diligence upon an insured event. Just as where no insurance contract exists, the policyholder who has an insurance contract must take basic measures to limit and reduce the damages that have occurred. It is elementary, ad exemplum, that where the bursting of a water pipe causes a flood in an apartment, the occupant of the apartment first has to attempt to shut off the water; or, where a storm damages a roof, one must call for a specialist to help prevent further damage that may be caused by rain in the future. The obligation to reduce damages is the first ex post obligation of the policyholder after an insured event-this being an own initiative obligation, i.e., the first responder normally cannot/has no time to ask for instructions from the insurer. Insofar as an insurance contract is made to address unexpected and unforeseen damages with an assumption that the policyholder behaves as customary, the failure to perform this obligation may give rise to the insurer's right to be in part or in full released from the performance obligation. This is a question about moral hazard; the tendency of people to change their behaviour if some downside risks of that behaviour are borne by others rather than themselves, as when those risks are covered by insurance. ${ }^{12}$

In addition to the policyholder's own-initiative obligation to reduce the damages, the insurers also take measures to reduce damages. For example, another way in which insurers regulate losses ex post is by helping to mitigate covered losses. This can be seen clearly in contractual provisions found in most insurance policies that require the insured to take all reasonable post-accident steps to mitigate losses or else forfeit coverage. Insurers also help the insured mitigate losses by monitoring repair services ${ }^{13}$. The policyholder is required to reduce and prevent damages from the moment when he became aware or must have become aware of the event that had occurred. From this moment onwards his conduct must be meaningful, i.e., his actions must be aimed at the prevention of realisation of the insured risk. The obligation to reduce and prevent damages must be assessed objectively, i.e., it must be borne in mind what a reasonable person

11 Jukka Rantala and Teivo Pentikäinen, Vakuutusoppi (Insurance Doctrine) (Sastamala: Finanssi- ja Vakuutuskustannus OY, 2009), p. 279 [in Finnish].

12 Lloyd R. Cohen and Michelle E. Boardman, "Methodology: applying economics to insurance law-an introduction": 28; in: Julian Burling and Kevin Lazarus, Research Handbook on International Insurance Law and Regulation (Edward Elgar Publishing Ltd., 2011).

${ }_{13}$ Omri Ben-Shahar and Kyle D. Logue, "Outsourcing Regulation: How Insurance Reduces Moral Hazard," Program in law and economics working paper series No. 12-004 (April 2012): 16 // http://papers.ssrn.com/sol3/papers.cfm?abstract_id=2038105 (accessed July 3, 2012). 
would or should do in a similar situation. Hence, an attempt to reduce or prevent damages is relevant, even where the given action was justified and performed faultlessly but the result was nil-in such a case the obligation to reduce or prevent damages is still deemed to have been performed. Thus, (i) a person is required to behave as if he has no coverage, and (ii) a person must behave like a reasonable person. The policyholder is required to perform the obligation to reduce and prevent damages up to the moment when he finds himself in danger, i.e., the policyholder is not required to put his life or health in danger or engage in criminal activity.

In Estonia, $\S 488$ (1) of LOA sets out that upon the occurrence of an insured event, the policyholder shall, insofar as is possible, attempt to prevent and reduce any damage and, in so doing, observe the instructions given by the insurer. If circumstances permit, the policyholder shall ask the insurer for such instructions. Hence, it is presumed under Estonian law that the policyholder must observe the insurer's instructions-such instructions are primarily the provisions set out in the general terms and conditions of the insurance contract. Ad exemplum, clause 59 of the General Insurance Conditions of the Estonian-based If $P \& C$ Insurance AS (hereinafter: If General Insurance Conditions) ${ }^{14}$ sets out that the policyholder will be obliged to apply the measures for restricting further damages, preventing potential additional loss and protecting the insurer's rights (e.g., by helping to detect the potential cause of the loss, the party creating the loss and the names of the witnesses). Janno Lahe has said that in assessing whether or not the prevention or reduction of damages was possible, attention should be paid to the details of the loss event. Thus, as a general rule, if, for instance, a fire breaks out, the policyholder must call the emergency services and not risk his life, attempting to retrieve things from the house on fire. Whether the policyholder can ask for instructions from the insurer depends on the circumstances of the loss event: first and foremost, on whether or not delaying action may increase the damages, but also on the possibility of getting in touch with the insurer. ${ }^{15}$ In Estonia, $\S 488$ (3) of the LOA sets out that if the policyholder violates the obligation specified in subsection (1) of the said section and the insurer sustains damage as the result thereof, the insurer shall have the right to reduce the indemnity by the extent of the damage sustained. Hence, in Estonia the insurer is released from the performance obligation to the extent that the indemnification of the insurer increased due to the policyholder's failure to take initiative to reduce the damages. For instance, in a situation where the door windows of a car are smashed in an

${ }^{14}$ General Insurance Conditions of the If P\&C Insurance AS //

http://tingimused.if.ee/ViewPDF.aspx?ID=441bd984-466f-4190-ad9f-1e4358b7e0bf (accessed July 3, 2012). 
accident and the policyholder leaves the windowless car in the rain for the night, the insurer does not have to compensate for the additional damages caused by rain. Furthermore, $\S \S 452$ (2) 3) and 4) of the LOA set a precondition that the violation must have been either intentional or due to gross negligence, and have bearing on establishing the occurrence of the insured event or the insurer's performance obligation. Thus, in the case of ordinary negligence, the insurer is not released from the performance obligation.

Article 6.1013.(1) of the Lithuanian CC sets out that upon occurrence of the insured event, the insured shall take reasonable accessible measures to mitigate the potential damage, following the insurer's instructions provided that such instructions have been given to the insured. Hence, the relevant Lithuanian regulation is similar to that of Estonia; however, it is not assumed in the CC that the policyholder should ask for instructions from the insurer. Article 6.1013 (3) of the $\mathrm{CC}$ sets out that the insurer shall be released from compensation of the damages if the damage was caused by the wilful failure of the insured to take reasonable accessible measures to mitigate or avoid such damage. Ad exemplum, clause 38.10.a of the Lithuanian-based insurance company Lietuvos Draudimas Home Insurance Policy Wording No. 064 (hereinafter: Lietuvos Draudimas Policy Wording $)^{16}$ sets out that during the effective period of the insurance contract the insured shall be obliged, after an event that may be recognised as insured, to take all reasonable and available actions to prevent further destruction of the property and attempt to reduce the level of loss. Hence, it is an analogous generally-worded obligation which most insurers stipulate in their general terms and conditions regarding damages. Clause 67.1 of the Lietuvos Draudimas Policy Wording sets out as a precondition of legal consequences that indemnity shall not apply to losses resulting from the fact that the insured or persons related to the insured (family members) did not, although could, take actions to rescue the insured property during and after the insured event, to ensure protection thereof and to prevent further damage.

Article 21 (1) of the Latvian ICL sets out that the insured shall inform the insurer of the occurrence of the insured event as soon as possible and shall act in all possible and reasonable ways to reduce the loss. Therefore, the Latvian regulation takes a further step compared with the relevant provisions of the Estonian and Lithuanian laws, demanding that action should be taken in all possible and reasonable ways. Accordingly, ad exemplum, clause 8.1.3 of the Latvian-based insurance company's BTA SE General Insurance Terms and Conditions No. 3

\footnotetext{
15 Janno Lahe, Kindlustusõigus (Insurance law) (Tallinn: Juura, 2007), p. 124 [in Estonian].

${ }^{16}$ Lietuvos Draudimas Home Insurance Policy Wording, no. 064 //

http://www.Id.It/uploads/files/dir52/dir2/13_0.php (accessed July 3, 2012).
} 
(hereinafter: BTA General Insurance Terms and Conditions) ${ }^{17}$ sets out that as a precondition for receiving the insurance indemnity, upon establishing the occurrence of the insured risk, the policyholder and the insured are obliged to take all measures in order to prevent or reduce further damages, as well as comply with BTA instructions as regards reducing the damage caused by occurrence of the insured risk. It is questionable whether such an 'all measures' requirement is reasonable. In Casco insurance, for instance, it is not presumed that an average driver would be capable of taking all measures to avoid a traffic accident: yes, a driver must be careful and observe the traffic code, however, accidents are often caused by the very fact that the policyholder was incapable of taking all the necessary measures. If we do not presume for the purposes of an insurance contract that the policyholder takes absolute care before an insured event, is it justified then to require this after the insured event takes place? Article 22 (1) of the ICL sets out that if the insured has not fulfilled any of the duties set out in Article 21 of the said law due to bad faith or gross negligence, the insurer is entitled to refuse to pay the insurance indemnity. While in the case of bad faith it is justified that the rights of the policyholder are not protected, it is still debatable whether gross negligence should fully release the insurer from the performance obligation. Article 22 (2) of the ICL sets out that the insurer may reduce the indemnity, but not more than $50 \%$, if the insured has not fulfilled any of the duties set out in Article 21 of the said law due to ordinary negligence. Hence, in Latvia, ordinary negligence of the policyholder entitles the insurer to reduce the indemnity by up to $50 \%$. In the same vein, clause 8.2 of the BTA General Insurance Terms and Conditions sets out that if the policyholder or the insured with malicious intent or at his or her fault, which in terms of reimbursement for losses and other civil liability consequences is considered malicious intent, does not fulfil any of the obligations referred to in the said clause, BTA is entitled to refuse to pay out the insurance indemnity. BTA may reduce the insurance indemnity, but by no more than $50 \%$ (fifty per cent), if the policyholder or the insured does not fulfil any of the obligations referred to in the said clause due to ordinary negligence. It is questionable why should ordinary negligence be something that restricts the performance obligation of the insurerone of the underlying reasons for entering into an insurance contract is the very same ordinary negligence of the policyholder.

The law in many countries contains what has been described as a 'duty' to avert loss that is imminent, and a 'duty' to mitigate loss that has occurred. However, these so-called duties are not duties in the usual sense of private law obligations actionable in damages, when unfulfilled. The impact of breach of these

\footnotetext{
${ }^{17}$ BTA SE General Insurance Terms and Conditions, no. 3 //
} 
'duties' is in the domain of causation: a breach of duty by a policyholder breaks the 'chain' of causation between the insured event and some or all of the resulting loss or damage, and to that extent insurers are not liable. Only a serious breach of such 'duties' is regarded as breaking the chain of causation. Otherwise the insurance would not cover policyholders' negligence. ${ }^{18}$ With the PEICL, the obligation to reduce damages and related legal consequences arises from Article 9:101. Paragraph 3 of the said article sets out that for the purposes of paragraphs 1 and 2, causation of loss includes failure to avert or to mitigate loss. Jürgen Basedow explains that paragraph 3 of Article 9:101 provides that these rules about culpability apply not only to the initial cause of loss but also to the response of policyholders to the occurrence of insured events for which they were not initially responsible-response to events which are imminent as well as events that have already occurred. The provision envisages cases in which policyholders, perhaps attracted by the prospect of insurance money, deliberately make little or no serious attempt to avert or mitigate loss, when such an attempt was viable, with the result that the extent of loss or damage is greater than it would have been, if policyholders' response had been less culpable. ${ }^{19}$ Article 9:101 (1) of the PEICL sets out that neither the policyholder nor the insured, as the case may be, shall be entitled to indemnity to the extent that the loss was caused by an act or omission on his part with intent to cause the loss or recklessly and with knowledge that the loss would probably result. Consequently, the relevant provision of the PEICL is much more customer-oriented than the Latvian regulation as the condition precedent to the insurer's release from the performance obligation is, as set out in the PEICL, an intent to cause the loss or recklessly and with knowledge that the loss would probably result. At the same time, the PEICL allows for other arrangements of the parties. However, such conditions must be negotiated separately. Article 9:101 (2) of the PEICL sets out that subject to a clear clause in the policy providing for reduction of the insurance money according to the degree of fault on his part, the policyholder or insured, as the case may be, shall be entitled to indemnity in respect of any loss caused by an act or omission on his part that was negligent. Such a regulation can be seen as justified-in a situation where the parties have, upon entering into an insurance contract, separately negotiated and agreed upon the insurer's obligations to reduce the damages after an insured event, it is clearly predictable and known to the policyholder. It is something that

http://www.bta.eu.com/files/29489_Visparejie_apdr_noteikumi_Nr.3_EN.pdf (accessed July 3, 2012).

18 Jürgen Basedow, John Birds, Malcolm Clark, Herman Cousy, and Helmut Heiss, Principles of European Insurance Contract Law (PEICL) (Munich: European Law Publishers GmbH, 2009), p. 247.

${ }^{19}$ Ibid., p 247. 
affected the insurer's decision to enter into the insurance contract subject to the given conditions, i.e., for the given insurance premium.

To sum up, it can be concluded that as things stand, amongst the Baltic States the most consumer-friendly regulations are in Lithuania and Estonia in terms of the obligation to reduce damages and the legal consequences of a failure to do so. Latvia, however, makes it possible for an insurer to be released from the performance obligation (in part or in full) also in situations which may contradict one of the purposes of an insurance contract: to have coverage also in the case of the policyholder's ordinary negligence. Enforcement of the PEICL would therefore significantly improve the protection of the rights of the consumer in Latvia.

\section{NOTIFICATION OF AN INSURED EVENT}

Notification of an insured event is the second important obligation of a policyholder. This obligation is important to enable the insurer to promptly take such important actions as: reducing damages, determining the extent of damages, indemnification and, where relevant, identification of the person who caused the damages. Without prompt ex post notification of an insured event, a situation may emerge in which the insurer cannot realise its rights to the extent necessary, possibly incurring additional costs and, in certain cases, rendering the insurer incapable of identifying the needed information. At the same time notification of the insured event ex post is important also for the policyholder, as it is the very trigger to receiving indemnity from the insurer.

In Estonia, § 448 (1) of the LOA sets out that a policyholder shall immediately notify the insurer of the occurrence of an insured event. Hence, under Estonian law prompt notification of an insured event is presumed. Ad exemplum, clause 58 of the If General Insurance Conditions sets out that the policyholder will inform the insurer about the insurance case immediately, in writing or by using a method that allows written reproduction (e.g., e-mail, a notice through the insurer's Internet home page). Hence, the insurer presumes that a notification must be given promptly and in writing. Subsection 449 (1) of the LOA sets out as the consequence of a failure to notify of an insured event that if an insurer suffers damage as the result of a violation of the obligation provided for in $\S 448$ of this Act, the insurer may reduce its performance obligation to the extent of such damage. In addition, $\S \S 449$ (2) of the LOA sets out that if the policyholder intentionally violates the obligation provided for in $\S 448$ of the Act, the insurer shall be released from its performance obligation. In Estonian legal literature, it has been held that consequences of an intentional violation of obligations should be distinguished from those of an unintentional violation. If the insurer suffers losses due to an 
unintentional violation of obligations, the insurer may reduce the performance obligation to that extent. This holds true even if the violation was excusable. One must bear in mind that the condition precedent to the application of the consequence set out in $\S 449$ (1) of the LOA is that the insurer has suffered a loss. Violation of the given obligation is not sufficient to reduce the performance obligation. The insurer may suffer losses, for example, in a situation where the consequence of the policyholder's violation of the obligation set out in $\S 448$ of the LOA is that the third persons responsible for the insured event cannot be identified and therefore the insurer cannot exercise its right of recourse. If the policyholder violates the obligation set out in $\S 448$ of the LOA intentionally, the insurer is released from the performance obligation. The condition precedent to the application of $\S 449$ (2) of the LOA is subsequently not the suffering of losses by the insurer as it suffices for the policyholder to have violated the obligation intentionally. ${ }^{20}$ The author does not agree with the concept that an insurer is always released from the performance obligation if the violation of the relevant obligation by the policyholder was intentional. There is no reasonable justification to release the insurer from the performance obligation in a situation where the policyholder's violation of the notification obligation was intentional but had no impact on the insurer's performance obligation. In 2001, however, the Estonian Supreme Court ${ }^{21}$ ruled that in a situation where a policyholder notified the insurer that a logging tractor had been stolen from him but forgot to report that together with the tractor also a lumber trailer had been stolen (there were two separate insurance contracts), the explanation later offered by the policyholder in the court to the effect that he had deemed the tractor to also include the trailer, treating them as a whole as they could be operated only together, had no bearing to the case, and therefore the insurer was entitled to refuse to pay indemnity due to the late notification. Thus, the Estonian court affirmed the insurer's release from the performance obligation due to the policyholder's late notification even if there is no causal link.

Article 6.1012 (1) of the Lithuanian CC sets out that the insured, having learned about the insured event, shall notify the insurer or its representative to that effect within the term and in the way stipulated in the agreement. The beneficiary shall have the same obligation if he knows about the insurance agreement concluded for his benefit and intends to exercise his right to the insurance indemnity. Accordingly, the Lithuanian CC presumes that the notification deadline is

\footnotetext{
${ }^{20}$ Paul Varul, Irene Kull, Villu Kõve, and Martin Käerdi, Võlaõigusseadus II. Kommenteeritud väljaanne (Law of Obligations Act II. Executive edition) (Tallinn: Juura, 2007), p. 531, point 3.1, pp. 488-489 [in Estonian].
} 
an object of the regulation provided in the general terms and conditions. Ad exemplum, clause 38.10.c of the Lietuvos Draudimas Policy Wording sets out that during the effective period of the insurance contract the insured shall be obliged, after an event that may be recognised as insured, to report the event to the insurer or to their representative within 24 hours (days off and national holidays are excluded) and provide them with detailed information about all the circumstances of such event known to the insured and, at the insurer's request, to confirm such event in writing and complete documents in the form established by the insurer within 3 business days. Such a 24-hour notification deadline, though protective of the insurer's rights, may under certain circumstances be too burdensome for the policyholder. For instance, in a situation where the policyholder's family loses their home to a fire, in the day/days following, the policyholder will obviously be busy with finding a temporary place for the family and might not have time to communicate with the insurer. Article 6.1012 (2) of the CC sets out as a legal consequence that if the insured (the beneficiary) fails to fulfil the obligation set forth in clause 1 of the said article, the insurer shall be entitled to refuse to pay the insurance indemnity or reduce it in consideration of whether the insured has failed to fulfil his obligation wilfully or through negligence, except for the cases when it is proved that the insurer has learned about the insured event in a timely manner or when the failure to notify about the insured event has no effect on the insurer's obligation to pay the insurance indemnity. Hence, the CC presumes that there is a causal link between the policyholder's violation and the insurer's performance obligation, i.e., in a situation where the violation has no bearing on the insurer's performance obligation, the insurer is not released from the indemnification obligation. On 10 May 2010, the Lithuanian Supreme Court concluded in civil case $3 \mathrm{~K}-3-210 / 2010^{22}$, that if a policyholder overruns the deadline for the notification of an insured event, there may be three consequences: (1) refusal to pay the insurance indemnity, (2) reduction of the insurance indemnity, or (3) late notification does not affect the obligations of the insurer if it can be proven that the insurer knew about the insured event, or the failure to notify does not affect the insurer's performance obligation. Hence, late notification does not mean automatically that the insurer is released from the performance obligation. The Lithuanian Supreme Court clarified that in the case of late notification, it must be determined whether the policyholder violated his obligation intentionally - if yes, the insurer is released from the performance obligation. If the policyholder violated

\footnotetext{
21 Jaanus Sarv v. Salva Kindlustuse AS, Supreme Court of the Republic of Estonia, 2001, no. 3-2-1-5601 [in Estonian] // http://www.nc.ee/?id=11\&indeks=0,2,10246,10419,10426\&tekst=RK/3-2-1-56-01 (accessed July 3, 2012).
} 
his obligations out of negligence, the indemnity may be reduced by the increase in the damages and only subject to the insurer proving that had it learned about the insured event on time, it would have taken measures to reduce the damages. The court emphasised that the burden of proof is on the insurer if it wants a release from the performance obligation. At the same time, it is the onus probandi of the policyholder that the insurer came into knowledge of the insured event on time or that the failure to notify had no impact on the insurer's performance obligation.

Article 21 (1) of the Latvian ICL, in turn, sets out that the insured shall inform the insurer of the occurrence of the insured event as soon as possible and shall act in all possible and reasonable ways to reduce the loss. Accordingly, in Latvia a policyholder is presumed to notify the insurer at the earliest possible moment. $A d$ exemplum, clause 8.1.1 of the BTA General Insurance Terms and Conditions sets out that as a precondition for receiving the insurance indemnity, upon establishing the occurrence of the insured risk, the policyholder and the insured are obliged to immediately, as soon as possible, inform BTA thereof at a place and in a way and form determined by BTA. If the policyholder or the insured informs BTA of the occurrence of the insured risk later than within 3 (three) working days after the occurrence of the insured risk, the policyholder or the insured shall prove that it was not possible to inform sooner. Such an obligation to notify at the earliest possible moment is reasonable as it allows the policyholder to justify the delayed notification with other vital needs, if such circumstances exist. As regards the legal consequences upon failure to give timely notification of an insured event, Article 22 (1) of the ICL sets out that if the insured has not fulfilled any of the duties set out in Article 21 of the said law due to bad faith or gross negligence, the insurer is entitled to refuse to pay the insurance indemnity. Release of the insurer from the performance obligation in case of bad faith is justified as the insurer cannot reward the policyholder for obstructing the insurer. At the same time, Article 22 (2) of the ICL sets out that the insurer may reduce the indemnity, but not more than $50 \%$, if the insured has not fulfilled any of the duties set out in Article 21 of the said law due to ordinary negligence. The author believes that instead, preference should be given to the approach that the insurer is released from the performance obligation to the extent in which the losses suffered by the insurer due to late notification increased, as it is difficult to argue why the insurer may reduce the indemnity by, let us say, $50 \%$ if the notification was delayed due to gross negligence, but it had no bearing on the amount of damages or did not complicate the insurer's clarification of the other aspects of the performance obligation.

22 UAB Arijus $v$. If P\&C Insurance AS, Supreme Court of the Republic of Lithuania, 2010, no 3K-3210/2010 [in Lithuanian] // http://www2.lat.lt/lat_web_test/getdocument.aspx?id=79d17bfb-a52c4ea2-b821-0431fc0508f7 (accessed July 3, 2012). 
Article 6:101 (1) of the PEICL sets out that the occurrence of an insured event shall be notified to the insurer by the policyholder, the insured or the beneficiary, as appropriate, provided that the person obliged to give notice was or should have been aware of the existence of the insurance cover and of the occurrence of the insured event. Notice by another person shall be effective. J. Basedow emphasises that the obligation to give notice of an insured event to the insurer on risk without undue delay applies (as a default rule) in all cases. No single person subject to the obligation is identified in Article 6:101. In practice, the person with an obvious interest in giving notice of an event is one or more of those referred to in Article 6:101 paragraph 1, who may do so personally or through an agent. As the rule is framed as an obligation, breach of which may have adverse consequences to those concerned, the provision concerning awareness is included to safeguard their position. ${ }^{23}$ Article $6: 101$ (2) of the PEICL sets out that such notice shall be given without undue delay. It shall be effective on dispatch. If the contract requires notice to be given within a stated period of time, such time shall be reasonable and in any event no shorter than five days. Consequently, compared with the LOA, CC and $I C L$, the PEICL is much more consumer-friendly by presuming notification without undue delay and providing that the notification deadline must be reasonable and not shorter than five days. The author believes that such an approach is justified as it allows the policyholder to first take care of vital needs in case of an accident (e.g., home loss in a fire) and not to prefer the interests of the insurer over the vitally primary interests of the policyholder. As regards the sanctions for the violation of the notification obligation, Article 6:101 (3) of the PEICL sets out that the insurance money payable shall be reduced to the extent that the insurer proves that it has been prejudiced by undue delay. Jürgen Basedow points out that the effect of breach of notice requirements varies in the law of European countries. In particular, there is no universal agreement about whether it is a condition of any sanction against claimants that insurers have been prejudiced by any undue delay. Article 6:101 paragraph 3 resolves this issue in favour of claimants. Moreover, first, as insurers usually raise breach of the notice duty as a ground for refusing to pay a claim, it is for insurers to prove prejudice which, in many if not most cases, insurers will find it either difficult or inexpedient to do. Second, it can be inferred that a reduction in the amount of insurance money payable, the remedy stated in Article 6:101 paragraph 3 , is the only sanction. Thus, insurers will not be allowed to plead policy terms whereby performance of a notice duty is a 'condition precedent' of payment of any insurance money at all. ${ }^{24}$

The regulation of insurance law is even more consumer-friendly in Finland,

\footnotetext{
23 Jürgen Basedow et al., supra note 18, p. 207.
} 
for instance. The Finnish Insurance Contract $\mathrm{Act}^{25}$ does not provide for an obligation to notify of an insured event. Jaana Norio-Timonen finds that the entitlement to insurance indemnity cannot be made conditional on the insurer's notification of an insured event during a certain period, e.g., within two weeks after the occurrence of the insured event. It is in the interests of the beneficiary to receive the indemnity as soon as possible. ${ }^{26}$ The author agrees with the approach of the Finnish legal theorists. It is difficult to argue why the insurer should be released from the indemnification obligation if it is notified of an insured event as late as five months after the event but the amount of loss or the clarification of the fact are not affected. For instance, in a situation where an apartment has been burglarised and the police have inspected the crime scene, nothing essentially changes for the insurer, as competent public servants have recorded the situation. Jaana Norio-Timonen points out that the provisions of Article $73^{27}$ of the Finnish Insurance Contract Act set out the indemnification deadline for the claimant by specifying the deadline for the making of claims and their expiry. This is built on the presumption that a claim for compensation under an insurance contract must be submitted to the insurer within one year of the moment when the claimant became aware of the in-force insurance contract, insured event and the damages caused by the insured event. $^{28}$

Accordingly, the PEICL will bring about a significant change for Estonian, Latvian and Lithuanian policyholders in terms of giving notice of an insured event. The PEICL is much more consumer-friendly and does not impose excessive restrictions on the policyholders as regards the deadlines applicable to insured events and the sanctions for potential violations. In Finland, however, the relevant regulation is even more consumer-friendly.

\section{COOPERATION OBLIGATION}

In terms of obligations after an insured event, the third main obligation is the cooperation obligation of the policyholder, i.e., the policyholder must facilitate the

\footnotetext{
${ }^{24}$ Ibid., p. 209.

${ }^{25}$ Finnish Insurance Contract Act (Vakuutussopimuslaki), no. 28.6.1994/543 [in Finnish] // http://www.finlex.fi/fi/laki/ajantasa/1994/19940543 (accessed July 3, 2012).

26 Jaana Norio-Timonen, Vakuutussopimuslain pääkohdat (The Main Points of Insurance Contract Act) (Helsinki: Talentum, 2010), p. 197 [in Finnish].

27 Article 73 of the Finnish Insurance Contract Act provides that any claims based on an insurance contract shall be made to the insurer within one year from the date at which the claimant becomes aware of an in-force insurance policy, of the occurrence of an insured event and of the loss, damage or injury that resulted from the occurrence. In any event, the claim shall be made within ten years from the occurrence of the insured event or, if the insurance has been taken out to cover against bodily injury or liability for damages, from the occurrence of the loss, damage or injury. Reporting the occurrence of an insured event is considered to equal the making of a claim for this purpose. If no claim is made within the period provided under Subsection 1, the claimant loses his entitlement to compensation.
} 
insurer's investigation of the circumstances of the insured event, identify the amount of loss and the persons responsible for the loss in order to exercise its subrogation rights, if necessary and so desired. ${ }^{29}$ Unless the policyholder performs the cooperation obligation, it would in many cases be difficult or even impossible for the insurer to handle the insured event, i.e., to determine the scope of its obligations and secure its right of recourse against the persons responsible for the loss. It is precisely in the interests of the policyholder to perform the cooperation obligation to the fullest so that his claim against the insurer is satisfied as soon as possible. Malcolm Clarke points out that while in notifying of an insured event, the initiative must emanate from the policyholder, in determining the scope of the insurer's performance obligation, initiative to gather information and evidence must be shown by the insurer. The general principle the insurers adhere to might be worded as follows: the higher is the indemnity claimed by a policyholder, the lower the trust of the insurers and the more evidence is requested from the policyholder. ${ }^{30}$

In Estonia, $\S 448$ (2) of the LOA sets out that an insurer may, after the occurrence of an insured event, request information from the policyholder which is necessary to determine the obligation to perform the contract. The insurer may request the submission of evidence insofar as the policyholder can reasonably be expected to submit such evidence. Ad exemplum, clause 8.1.5 of the Estonianbased Seesam Insurance AS Motor Vehicle Insurance Conditions 1/2012 (hereinafter: Seesam Motor Vehicle Insurance Conditions) ${ }^{31}$ sets out that the policyholder is under obligation to prove the occurrence of an insured event and the scope of damage and give Seesam information needed for proving the contract performance obligation. If the circumstances of the loss event cannot be established based on available information, Seesam has the right to suspend the loss adjustment procedure until receiving all necessary information, informing the insurer thereof in a format which can be reproduced in writing. An insurer that conducts business in keeping with good practices and morals, guided by ius non scriptum, would request the necessary documents from the policyholder all at once ${ }^{32}$ without any delaying tactics, i.e., it would not request for another document

\footnotetext{
28 Jaana Norio-Timonen, supra note 26, p. 197.

29 See, e.g., clause 61 of the If general insurance conditions which set out that in the event of loss, the policyholder will be obliged to give the insurer true and complete information about the circumstances of the loss, the amount of loss and the persons who are potentially responsible.

30 Malcolm Clarke, Policies and Perceptions of Insurance Law in the Twenty-First Century (Oxford University Press, 2005), p. 198.

${ }^{31}$ Seesam Insurance AS Motor Vehicle Insurance Conditions, 1/2012 //

http://seesam.ee/uploads/files/car-

insurance/S\%C3\%B5idukikindlustuse_tingimused_1_2012_(22032012)_ENG.pdf (accessed July 3, 2012).

32 For instance, in the "Principles of Claim Handling" established by the Finnish Association of Insurance Companies, the Finnish insurers have assumed this obligation in writing and beyond the law (Principles of Claim Handling Established by the Finnish Association of Insurance Companies [in Finnish] //
} 
after the policyholder has submitted a document, if such a request could have been presented immediately.

The cooperation obligation may give rise to the question of the extent to which the insurer may request proof from the policyholder. ${ }^{33}$ For instance, does the insurer have the right to request that the policyholder produces all the acquisition documents for the items which were stolen or destroyed in a fire or, in other words, is this the onus probandi of the policyholder? ${ }^{34}$ The Supreme Court of the Republic of Estonia ruled in its 28.11 .2007 judgement No. 3-2-1-106-07 ${ }^{35}$ that the submission, ex ante or ex post an insured event, of the acquisition documents of stolen items to the insurer does not prove per se that the items existed at the moment when the insured event occurred. Here too it is presumed, for the benefit of the policyholder, that the items did exist. The insurer may challenge the presumption, i.e., it may prove the opposite. The insurer may also turn to the police if it has suspicions regarding the crime. The court concluded that a standard term which requires the policyholder to submit acquisition documents is void. Furthermore, the second sentence of $\S 448$ (2) of the LOA sets out that the insurer may request the submission of evidence insofar as the policyholder can reasonably be expected to submit such evidence. It is not necessarily reasonable to request evidence for the existence of less valuable items (such as DVDs) as it cannot be normally expected that a reasonable person has kept the acquisition documents. However, this presumption does not always hold true-if the policyholder invokes the lack of evidence on the existence of the stolen items and the statements regarding the circumstances of acquiring the stolen items are utterly unreasonable, then the insurer may still be released from the performance obligation. Finnish jurisprudents believe that the claimant must present the information and explanations which can justifiably requested from him, however, the feasibility of procuring evidence by the policyholder should also be taken into account. Consequently, it is the insurer who must collect evidence, as usually the insurer is

http://www.fkl.fi/materiaalipankki/ohjeet/Dokumentit/Korvaustoiminnan_periaatteet.pdf (accessed July 3, 2012).

${ }^{33}$ See, e.g., clause 63 of the If general insurance conditions which sets out that the policyholder will submit to the insurer documents, written explanatory statements, answer to the insurer's questions both orally and in writing, on the insurer's request to participate in the inspection of the scene of the event or of the damaged property.

34 See, e.g., clause 38.10 of the Lietuvos Draudimas Policy Wording which sets out that during the effective period of the insurance contract the Insured shall be obliged to after an event that may be recognised as insured: f) provide the Insurer with all documents related to the event and/or indicated by the Insurer which are required to identify reasons for destruction or damaging of the property and to assess the level of loss, including: - report of the event;- in the event of disappearance, destruction or damaging of home property provide the Insurer with a list of damaged, disappeared or destroyed items (indicating the buying year and price of the items), invoices for rescuing costs and repair of damaged property, purchase invoices and receipts, user manuals and other documentation required to identify the causes and circumstances of destruction or damaging, the level of loss and the culprit as well as evidence (purchase documentation, photos and other objective evidence of possessing the item) of possessing those items in the event of burglary or robbery where the value per item exceeds 2,000 Lt. 
better positioned to do this thanks to its staff. The method of producing evidence depends on the facts of each single case. Notwithstanding, the onus probandi of the claimant covers those circumstances regarding which he is in a better position to produce proof than the insurer. The obligations of the claimant also include clarification and reporting of the facts that are not to his benefit. One of the most important duties of insured in the insurance contract is to inform the insurer, fully and accurately. In its 18.12.2007 decision No. 2-04-111 $1^{37}$ the Tallinn Circuit Court ruled that in a situation where the insurer could prove on the basis of the balances of the policyholder for the previous years that the policyholder did not have the turnover or assets to acquire the allegedly stolen items, the claim of the policyholder must be dismissed. The court found that the fact that insurance fraud was not identified in the criminal case does not preclude assuming a position as to the occurrence of the insured event in a civil case.

The cooperation obligation also contains the obligation to keep the damaged item in the state it was in ex post the insured event so that the insurer can examine it. ${ }^{38}$ In this vein, $\S 488$ (2) of the LOA sets out that prior to damage being established, the policyholder shall not make any changes with respect to the damaged thing without the permission of the insurer if such changes would hinder or render impossible establishment of the cause or extent of the damage, unless the change is necessary to reduce the damage or in the public interest. The obligation contained in $\S 488$ (2) of the LOA means that without the consent of the insurer the policyholder must in no way alter the damaged item before the damages have been established, if this would complicate or render impossible the insurer's clarification of the cause or extent of damages, except where the alteration is necessary to reduce the damage or is in public interest. ${ }^{39}$ Subsection 488 (3) of the LOA sets out as a sanction that if the policyholder violates the obligation specified in subsection (2) of the said section and the insurer sustains damage as the result thereof, the insurer shall have the right to reduce the indemnity by the extent of the damage sustained. If the policyholder alters the damaged item in breach of the obligation, the fact that this complicated the

${ }^{35}$ Margus Saks v. AS If Eesti Kindlustus, Supreme Court of the Republic of Estonia, 2007, no. 3-2-1-10607 [in Estonian] // http://www.nc.ee/?id=11\&tekst=RK/3-2-1-106-07 (accessed July 3, 2012).

${ }^{36}$ Esko Hoppu and Mika Hemmo, Vakuutusoikeus (Insurance Law) (Porvoo: WS Bookwell OY, 2006), p 1258 [in Finnish].

37 OÜ Valboreks v. ERGO Kindlustuse AS, Tallinn Circuit Court, 2007, no. 2-04-111 [in Estonian] // http://www.kohus.ee/kohtulahendid/temp/2-04-111.pdf (accessed July 3, 2012).

38 See, e.g., clause 6.1.4. of the Latvian-based insurance company BTA SE Home Insurance conditions No. 3F-2: "Upon establishing the occurrence of a possible insurable event, the Policyholder is obliged within the possibilities to preserve the site untouched and immediately inform BTA of the time and place, when and where a BTA representative could arrive and inspect the damaged insurance object in order to assess the incurred damages, as well as to check on the possible insurable event and its circumstances" (BTA SE Home Insurance conditions, no. 3F-2 //

http://www.bta.eu.com/files/25151_Majoklu_apdrosinasanas_noteikumi_3F-2_EN.pdf (accessed July 3, 2012).

39 Paul Varul et al., supra note 20, p. 531. 
clarification of the circumstances of the loss event for the insurer should not, per se, be the basis of the incurred damages or the basis on which to reduce the indemnity. The insurer must prove that it incurred additional costs due to the alteration which did not serve the purpose of reducing the damage or was not in the public interest. ${ }^{40}$

The cooperation obligation is paired with the common requirement of insurers that ex post, in case of occurrence of an insured event, the policyholder must report the event to the competent authorities. For instance, in case of a fire, to the rescue service, in case of a traffic accident-to the traffic police, in case of a theftto the police, etc. ${ }^{41}$ Clause 65.2 of the Lietuvos Draudimas Policy Wording sets out that indemnity shall not be payable where the fact of theft was not confirmed by the police and also for items the disappearance of which during an insured event was not reported to the police by the insured. This requirement secures the insurer's performance obligation. For instance, reporting a theft to the police may afford the insurer the possibility that the police identifies the thief and the insurer is thus able to exercise its subrogation rights. The obligation to notify the rescue service of a fire also secures the obligation to reduce damages. The Estonian Supreme Court ${ }^{42}$ has ruled that such general terms and conditions which require the registration of a traffic accident in keeping with the current legislation do not unreasonably prejudice the policyholder, i.e., they do not constitute a breach of the reasonable expectations doctrine. In the cited case, a car rental company had brought charges against an insurer who had refused to pay indemnity for damages caused by a traffic accident (the case involved the casco insurance of a vehicle of the rental company). In this traffic accident, the driver had left the scene of the accident. It was established later that the vehicle had been rented against false documents. A representative of the car rental company immediately arrived at the scene. The insurer argued that the fact that a representative of the car rental company immediately arrived at the scene of the traffic accident is not sufficient to deem that the policyholder had performed its obligations. Under the terms of insurance, the insurer may refuse to pay the indemnity if, at the time of the insured

\footnotetext{
40 Ibid.

${ }^{41}$ See, e.g., clause 57 of the If General Insurance Conditions: "In the occurrence of an insurance event (damage to, or destruction of the insured object, creation of insured expenses, bodily injury, a claim being made, etc.), the policyholder will act according to the order stipulated in legal acts and, depending on the nature of the event, to report immediately to the police, fire brigade or other body involved with respective rescue work or the investigation of the circumstances of the case." Likewise, clause 8.1.2 of the BTA General Insurance Terms and Conditions: "As a precondition for receiving the insurance indemnity, upon establishing the occurrence of the insured risk, the Policyholder and the Insured are obliged to immediately inform the state authorities whose competence is to investigate a respective event or provide rescue services in the way and form determined by BTA (e.g. Fire Rescue Service, State Police, Road Police, etc.)".

42 OÜ Autorent ja Kinnisvara Q v. ERGO Kindlustuse AS, Supreme Court of the Republic of Estonia, 2001, no. 3-2-1-88-04 [in Estonian] // http://www.nc.ee/?id=11\&tekst=RK/3-2-1-88-04 (accessed July 3, 2012).
} 
event, the person who drove the vehicle was driving under the influence of alcohol, drugs or psychotoxical substances or if the driver did not have a driver's licence of the proper category. For the purpose of establishing such circumstances, the terms include the policyholder's obligation to duly report and execute a traffic accident. As the driver fled the scene in breach of the traffic code, the insurer was incapable of establishing the facts which were vital for the payment of the indemnity. However, the Tartu Circuit Court concluded in its 07.11.2011 decision No. 2-10-14648 ${ }^{43}$ that by violating such an obligation (to report a traffic accident to the police), the policyholder stripped the insurer of the opportunity to gather evidence on whether or not there were circumstances present before the insured event which increased the likelihood of the insured risk. Due to the policyholder's breach, there was no information whatsoever in the case regarding the traffic-technical mechanism of the vehicle driving off road and the cause of the traffic accident. Accordingly, the court found that the reduction of the amount ordered from the insurer by $50 \%$ was justified.

Another question in connection with the cooperation obligation is: what happens if the insurer cannot verify the performance of certain obligations by the policyholder? For instance, in Casco insurance, driving under the influence of alcohol is one of the circumstances that precludes the insurer's performance obligation. It is one of the main reasons why drivers often leave the scene after a traffic accident in breach of the rules. But what happens if a policyholder maintains that he consumed alcohol after the accident, but before the police arrived? In its 31.08.2009 decision No. 2-08-373744, the Tallinn Circuit Court affirmed the release of the insurer from the performance obligation in such a situation. The court found that consuming alcohol after an accident directly affects the clarification of the facts of the loss. Engaging in such activity precludes, inter alia, the establishment of intoxication which, in turn, hinders the insurer's determination of the scope of the obligation to perform the insurance contract.

Article 96 (1) of the Lithuanian IL sets out that the policyholder, beneficiary and/or any injured party must provide to the insurer all the documents and information available to him about the circumstances and consequences of the insured event which are necessary in order to establish the amount of the benefit. At the request of the insurer, the above-mentioned persons must also provide documents about the circumstances and consequences of the insured event necessary for establishing the amount of the insured event which they are entitled to obtain following the procedure established by laws and other legal acts. The

43 oÜ Sepmar v. BTA apdrošināšanas akciju sabiedrība, Tartu Circuit Court, 2011, no. 2-10-14648 [in Estonian] // http://www.kohus.ee/kohtulahendid/temp/2-10-14648.pdf (accessed July 3, 2012). 
insurance contract must indicate what documents have been provided to the insurer. A similar regulation is contained in clause 38.10 of the Lietuvos Draudimas Policy Wording, which requires that during the effective period of the insurance contract the insured shall be obliged to after an event that may be recognised as insured $\mathrm{g}$ ) enable the insurer to investigate the event without restriction (access to property administration, acquisition, sale, lease, etc. documentation) and fulfil other lawful requirements of the insurer; $h$ ) assist the insurer in exercising their right of regress and provide the Insurer will all information to the knowledge of the insured about the person responsible for the damage caused; i) provide the police with a list of disappeared, destroyed or damaged items. The actions referred to above may also be performed by an adult member of the Insurer's family or a person authorised by the insured with a notary's certification to represent them in insurance companies. Hence, the Lithuanian IL and Estonian LOA have similar provisions regarding the cooperation obligation of the policyholder.

Article 21 (2) of the Latvian ICL sets out that the insured may not object to the insurer's requirement to determine and assess the amount of loss and circumstances causing the loss, and the insured shall submit to the insurer all the documents possessed by him/her, describing the occurrence of the insured risk and the loss incurred. The insured shall also provide other information possessed by him/her which is required by the insurer and fulfil other duties, as stated in the insurance contract. For example, clause 8.1.6 of the BTA General Insurance Terms and Conditions sets out that as a precondition for receiving the insurance indemnity, upon establishing the occurrence of the insured risk, the policyholder and the insured are obliged to submit all information and documents requested by BTA, including those containing commercial secrets, if they are available to the policyholder or the insured, so that BTA can determine the causes of the possible insurable event and the amount of damage. The author finds the submission of information containing commercial secrets extremely questionable-if immediate commercial secrets are involved, the information can be substantiated by different means: for instance, in the auditor's opinion (and so forth). Article 22 (1) and (2) of the Latvian ICL set out as sanctions that if the insured has not fulfilled any of the duties set out in Article 21 of the said law due to bad faith or gross negligence, the insurer is entitled to refuse to pay the insurance indemnity and the insurer may reduce the indemnity, but not more than $50 \%$, if the insured has not fulfilled any of the duties set out in Article 21 due to ordinary negligence. In this issue too, the regulation of the Latvian ICL allowing the reduction of the indemnity by up to $50 \%$ is questionable. It would be justified and reasonable for the insurer to be released

${ }^{44}$ Irina Malantšuk v. Seesam Rahvusvaheline Kindlustuse AS, Tallinn Circuit Court, 2009, no. 2-08-3737 
from the performance obligation to the extent in which the establishment of the insurer's performance obligation was rendered impossible due to the policyholder's failure to fulfil the cooperation obligation.

There is also the question about the legal consequences in a situation where the policyholder lies about the circumstances of an insured event, i.e., the policyholder intentionally violates the cooperation obligation in order to mislead the insurer about the facts of the damage, i.e., the policyholder operates mala fide. For instance, clause 65.1 of the Lietuvos Draudimas Policy Wording sets out that indemnity shall not be payable where the insured, persons related to the insured or the beneficiary, attempted to mislead the insurer by falsifying the facts or providing incorrect data or took actions to receive or increase indemnity without valid grounds. Finnish jurisprudents believe that the claimant's indemnity may be reduced or the pay-out refused if the claimant provided false information to the insurer after an insured event or omitted information about circumstances which are relevant for the determination of the insurer's performance obligation. The issue is weighed based on what is reasonable in view of the circumstances. Any act is explored from the aspect of whether it was conscious submission of false information, and of its relevance for the insurer as well as of the benefits it brought to the policyholder. ${ }^{45}$ The Tallinn Circuit Court concluded in its 19.06.2009 decision No. $2-07-43148^{46}$ that the insurer is entitled to refuse to pay indemnity in a situation in which the policyholder produced to the insurer just one set of keys after the theft of the vehicle and, as stated in the claim application, handed over one set of keys to the police although later it appeared that this set had not actually been delivered to the police as it had been stolen from the policyholder in a café where they had been left unattended in the coat pocket. The court found that although the policyholder is the weaker party to an insurance relationship, the insurer may refuse to pay the indemnity if the insurer was given false information about the circumstances of the event due to which the actual circumstances of the origin of the damages, the indemnification obligation of the insurer and the scope of it cannot be determined. The determination of these circumstances is a major interest for the insurer so as to prevent insurance fraud. Insofar as it was established that the loss event must have occurred under different circumstances, it could not be precluded that the loss event occurred under circumstances which preclude the indemnification obligation. Thus, the insurer was justified in refusing to perform its obligation.

[in Estonian] // http://www.kohus.ee/kohtulahendid/temp/otsus.pdf (accessed July 3, 2012).

45 Katriina Lehtipuro, Irene Luukkonen, and Lea Mäntyniemi, Vakuutuslainsäädänto (Insurance Legislation) (Sastamala: Finanssi- ja Vakuutuskustannus OY, 2010) [in Finnish].

${ }^{46}$ Sergei Vasenkin v. Seesam Rahvusvahelise Kindlustuse AS, Tallinn Circuit Court, 2009, no. 2-0743148 [in Estonian] // http://www.kohus.ee/kohtulahendid/temp/otsus.pdf (accessed July 3, 2012). 
One more question goes along with the cooperation obligation after an insured event: if, in connection with an insured event (e.g., traffic accident, fire, etc.), criminal proceedings have commenced in the course of which circumstances relevant to the insurer are to be clarified, would this postpone the insurer's performance obligation ${ }^{47}$ Do such proceedings involve the policyholder's cooperation obligation? In its 08.04.2008 decision No. 2-06-6604 ${ }^{48}$, where the insurer justified the postponement of performance with criminal proceedings, the Tallinn Circuit Court ruled that the provisions in the insurer's general terms and conditions for the postponement of the pay-out in case of administrative, civil or criminal proceedings or department investigation are unilateral and unreasonable as they violate the reasonable expectations doctrine. Such a standard term is void $^{49}$, as it is a generally worded provision which in essence entitles the insurer ad extra unlimited opportunities to postpone the performance of its obligations. This provision renders to the user of the general terms and conditions a formal basis to refuse to perform the obligation due to circumstances unrelated to the insured event. The court found that non-payment of the indemnity by the insurer to the policyholder until the identification of the culprit in the criminal proceedings cannot be considered to be reasonable. No evidence was put forward to indicate that the policyholder was a suspect in the proceedings-which would obstruct the rendering as a decision to indemnify. The policyholder himself approached the police with a request to commence criminal proceedings. Hence, the policyholder behaved as a reasonable person and it would be unreasonable to punish him for that. Refusal to decide on the indemnification and pay the indemnity for an indeterminate number of years is contrary to the purpose of insurance and renders the purpose of the insurance contract ad absurdo.

Article 6:102 (1) of the PEICL sets out that the policyholder, insured or beneficiary, as appropriate, shall cooperate with the insurer in the investigation of the insured event by responding to reasonable requests, in particular for information about the causes and effects of the insured event, documentary or other evidence of the insured event, and access to premises related thereto. Jürgen Basedow points out that such information may be necessary if insurers are to investigate the claim or seek to mitigate the extent of the insured loss. Accordingly, a duty to cooperate on this and other respects is sometimes implied in the law of

\footnotetext{
47 See, e.g., clause 10.2 of the Seesam Motor Vehicle Insurance Insurance Conditions: "If criminal proceedings have been brought in connection with the insured event, Seesam has the right to postpone making a decision until receiving the decision on finishing the criminal proceedings."

${ }^{48}$ Liis Kommesaare v. QBE Kindlustuse Eesti AS, Tallinn Circuit Court, 2008, no. 2-06-6604 [in Estonian] // http://www.kohus.ee/kohtulahendid/temp/2-04-6604.pdf (accessed July 3, 2012).

${ }_{49}$ Angelo Borselli points out that according to Article 3.1 of the European Union Directive 93/13/EEC of 5 April 1993 and to Article 2:304(1) PEICL, a term not individually negotiated is unfair if, 'contrary to the requirement of good faith, it causes a significant imbalance in the parties' rights and obligations arising
} 
European countries as an aspect of the mutual duty of good faith. Such duty is confirmed by article 6:102. The duty must be performed by the policyholder, insured or beneficiary, as the case may be: the person or persons to whom the request for information is made. The duty does not extend to more intrusive mattes, such as giving insurers access to financial information, or to more stressful matters such as submission for examination under oath. Nor does it extend to a duty, sometimes found in liability policies, to attend the proceedings of court or tribunal. The duty does not extend, however, to reasonable requests for information that might assist a defence to actions brought against liability policyholders $^{50}$ Article 6:102 (2) of the PEICL sets out as a sanction that in the event of any breach of paragraph 1 and subject to paragraph 3, the insurance money payable shall be reduced to the extent that the insurer proves that it has been prejudiced by the breach. Hence, the PEICL too prefers not to 'punish' the policyholder but reduce the indemnity to the extent in which the cooperation obligation was violated. As regards policyholders who operate mala fide, Article 6:102 (3) of the PEICL is applied under which in the event of any breach of paragraph 1 committed with intent to cause prejudice or recklessly and with knowledge that such prejudice would probably result, the insurer shall not be obliged to pay the insurance money.

Hence, the PEICL makes the Estonian, Latvian and Lithuanian more consumer-friendly in the realm of the cooperation obligation as well. The insurers must consider the interests of the policyholders more (e.g., in respect of not giving away of commercial secrets).

\section{CONCLUSIONS}

Compared with national laws of the Baltic States, the relevant regulation provided in the PEICL is more favourable and consumer-friendly for policyholders. It would be in the interests of the Baltic policyholders that the PEICL would be promptly enforced as a so-called 2nd regime instrument in the European Union. The 2nd regime allows for insurers who operate in several countries to harmonise their insurance products, which in turn facilitates the provision of cheaper and more comprehensible insurance products to the consumers. Upon the enforcement of the 2nd regime, a person relocating to live or work in another country does not need to familiarise himself with a different regulation of insurance contracts. The three key obligations after insured event, i.e., (i) the obligation to reduce damage, (ii) the 
obligation to report an insured event, and (iii) the obligation to cooperate, play a major role in the performance obligation of the insurer. Breach of those obligations may in certain cases result in the refusal to pay insurance indemnity. Among the Baltic States, Lithuania and Estonia have the consumer-friendliest regulations regarding the obligation to reduce damages and the related legal consequences of violating that obligation. Latvia, however, makes it possible for an insurer to be released from the performance obligation (in part or in full) also in situations which may contradict one of the purposes of an insurance contract: to have coverage also in the case of the policyholder's ordinary negligence. The enforcement of the PEICL would therefore also significantly improve protection of the rights of the consumer in Latvia. The PEICL will bring about a significant change for Estonian, Latvian and Lithuanian policyholders in terms of giving notice of an insured event. The PEICL is much more consumer-friendly and does not impose excessive restrictions on the policyholders are regards the deadlines applicable to insured events and the sanctions for potential violations. It is noteworthy, however, that in Finland, the relevant regulation is even more consumer-friendly. In terms of the cooperation obligation, the PEICL means that Estonian, Latvian and Lithuanian insurers must take the interests of policyholders into account more.

\section{BIBLIOGRAPHY}

1. Basedow, Jürgen, John Birds, Malcolm Clark, Herman Cousy, and Helmut Heiss. Principles of European Insurance Contract Law (PEICL). Munich: European Law Publishers GmbH, 2009.

2. Ben-Shahar, Omri, and Kyle D. Logue. "Outsourcing Regulation: How Insurance Reduces Moral Hazard." Program in law and economics working paper series No. 12-004 (April 2012) // http://papers.ssrn.com/sol3/papers.cfm?abstract_id=2038105 (accessed July 2, 2012).

3. Borselli, Angelo. "Unfair Terms in Insurance Contracts." Insurance Law Review No. 2 (2011).

4. Clarke, Malcolm. Policies and Perceptions of Insurance Law in the Twenty-First Century. Oxford University Press, 2005.

5. Cohen, Lloyd R., and Michelle E. Boardman. "Methodology: applying economics to insurance law-an introduction": 19-32. In: Julian Burling and Kevin Lazarus. Research Handbook on International Insurance Law and Regulation. Edward Elgar Publishing Ltd., 2011.

6. Doract, Walter. "The Optional European Contract Law and why success or failure may depend on scope rather than substance." Max Planck Private Law 
Research Paper No. 11/9. (June 25, 2011) //

http://papers.ssrn.com/sol3/papers.cfm?abstract_id=1876451

(accessed August 10, 2012).

7. Heiss, Helmut, Malcolm Clarke, and Mandeep Lakhnan. "Europe: Toward a harmonised European insurance contract law-the PEICL": 603-621. In: Julian Burling and Kevin Lazarus. Research Handbook on International Insurance Law and Regulation. Edward Elgar Publishing Ltd., 2011.

8. Hoppu, Esko, and Mika Hemmo. Vakuutusoikeus (Insurance Law). Porvoo: WS Bookwell OY, 2006 [in Finnish].

9. Lahe, Janno. Kindlustusõigus (Insurance law). Tallinn: Juura, 2007 [in Estonian].

10. Lehtipuro, Katriina, Irene Luukkonen, and Lea Mäntyniemi. Vakuutuslainsäädänto (Insurance Legislation). Sastamala: Finanssi- ja Vakuutuskustannus OY, 2010 [in Finnish].

11. Low, Gary. "Will firms consider a European optional instrument in contract law?" European Journal of Law and Economics Vol. 33, No. 3 (2012): 521-540 // DOI: 10.1007/s10657-011-9276-1.

12. Norio-Timonen, Jaana. Vakuutussopimuslain pääkohdat (The Main Points of Insurance Contract Act). Helsinki: Talentum, 2010 [in Finnish].

13. Rantala, Jukka, and Teivo Pentikäinen. Vakuutusoppi (Insurance Doctrine). Sastamala: Finanssi- ja Vakuutuskustannus OY, 2009 [in Finnish].

14. Rühl, Giesela. "Information Obligations (Insurance Contracts)". In: Jürgen Basedow, Klaus Hopt, and Reinhard Zimmermann, eds. Encyclopaedia of European Private Law. Oxford University Press, 2012 // http://papers.ssrn.com/sol3/papers.cfm?abstract_id=1989536 (accessed July 2, 2012).

15. Varul, Paul, Irene Kull, Villu Kõve, and Martin Käerdi. Võlaõigusseadus II. Kommenteeritud väljaanne (Law of Obligations Act II. Executive edition). Tallinn: Juura, 2007 [in Estonian].

\section{LEGAL REFERENCES}

1. BTA SE General Insurance Terms and Conditions. No. 3. // http://www.bta.eu.com/files/29489_Visparejie_apdr_noteikumi_Nr.3_EN.pdf (accessed July 3, 2012).

2. BTA SE Home Insurance conditions. No. 3F-2 // http://www.bta.eu.com/files/25151_Majoklu_apdrosinasanas_noteikumi_3F2_EN.pdf (accessed July 3, 2012).

3. Draft Common Frame of Reference. Chapter III, Section IX: Insurance 
Contract. Project Group "Restatement of European Insurance Contract Law" (August 2009) //

http://www.uibk.ac.at/zivilrecht/restatement/sprachfassungen/peicl-en.pdf (accessed July 3, 2012).

4. European Parliament Resolution of 8 June 2011 on Policy Options for Progress towards a European Contract Law for Consumers and Businesses. 2011/2013(INI) //

http://www.europarl.europa.eu/sides/getDoc.do?type=TA\&language=EN\&refe rence $=$ P7-TA-2011-0262 (accessed July 3, 2012).

5. Finnish Insurance Contract Act. No. 28.6.1994/543 // http://www.finlex.fi/fi/laki/ajantasa/1994/19940543 (accessed July 3, 2012).

6. General Insurance Conditions of the If P\&C Insurance AS // http://tingimused.if.ee/ViewPDF.aspx?ID=441bd984-466f-4190-ad9f1e4358b7e0bf (accessed July 3, 2012).

7. Irina Malantšuk v. Seesam Rahvusvaheline Kindlustuse AS. Tallinn Circuit Court, 2009, no. 2-08-3737 [in Estonian] // http://www.kohus.ee/kohtulahendid/temp/otsus.pdf (accessed July 3, 2012).

8. Jaanus Sarv v. Salva Kindlustuse AS. Supreme Court of the Republic of Estonia, 2001, no. 3-2-1-56-01 [in Estonian] // http://www.nc.ee/?id=11\&indeks=0,2,10246,10419,10426\&tekst=RK/3-2-156-01 (accessed July 3, 2012).

9. Law of Obligations Act (Estonia). State Gazette (Riigi Teataja), part 1, July 18, 2011 , no. 21.

10. Law on Insurance (Lithuania). Official Gazette (Valstybės žinios), 2003, no. 94-4246.

11. Lietuvos Draudimas Home Insurance Policy Wording. No. 064 // http://www.Id.It/uploads/files/dir52/dir2/13_0.php (accessed July 3, 2012).

12. Liis Kommesaare v. QBE Kindlustuse Eesti AS. Tallinn Circuit Court, 2008, no. 2-06-6604 [in Estonian] // http://www.kohus.ee/kohtulahendid/temp/otsus.pdf (accessed July 3, 2012).

13. Margus Saks v. AS If Eesti Kindlustus. Supreme Court of the Republic of Estonia, 2007, no 3-2-1-106-07 [in Estonian] // http://www.nc.ee/?id=11\&tekst=RK/3-2-1-106-07 (accessed July 3, 2012).

14. OÜ Autorent ja Kinnisvara $Q v$. ERGO Kindlustuse AS. Supreme Court of the Republic of Estonia, 2001, no. 3-2-1-88-04 [in Estonian] // http://www.nc.ee/?id=11\&tekst=RK/3-2-1-88-04 (accessed July 3, 2012).

15. OÜ Sepmar v. BTA apdrošināšanas akciju sabiedrība. Tartu Circuit Court, 2011, no 2-10-14648 [in Estonian] // http://www.kohus.ee/kohtulahendid/temp/2-10-14648.pdf 
(accessed July 3, 2012).

16. OÜ Valboreks v. ERGO Kindlustuse AS. Tallinn Circuit Court, 2007, no 2-04111 [in Estonian] // http://www.kohus.ee/kohtulahendid/temp/2-04-111.pdf (accessed July 3, 2012).

17. Principles of Claim Handling Established by the Finnish Association of Insurance Companies [in Finnish] //

http://www.fkl.fi/materiaalipankki/ohjeet/Dokumentit/Korvaustoiminnan_peri aatteet.pdf (accessed July 3, 2012).

18. Seesam Insurance AS Motor Vehicle Insurance Conditions. 1/2012 // http://seesam.ee/uploads/files/carinsurance/S\%C3\%B5idukikindlustuse_tingimused_1_2012_(22032012)_ENG. pdf (accessed July 3, 2012).

19. Sergei Vasenkin v. Seesam Rahvusvahelise Kindlustuse AS. Tallinn Circuit Court, 2009, no. 2-07-43148 [in Estonian] // http://www.kohus.ee/kohtulahendid/temp/2-04-6604.pdf (accessed July 3, 2012).

20. The Civil Code of the Republic of Lithuania. Official Gazette (Valstybès žinios), 2000, no. 74-2262.

21. The Insurance Contract Law (Latvia). Latvian Herald (Latvijas Vēstnesis), no. 188/189, June 30, 1998; no. 15.

22. $U A B$ Arijus $v$. If $P \& C$ Insurance $A S$. Supreme Court of the Republic of Lithuania, 2010, no 3K-3-210/2010 [in Lithuanian] // http://www2.lat.lt/lat_web_test/getdocument.aspx?id=79d17bfb-a52c-4ea2b821-0431fc0508f7 (accessed July 3, 2012). 